\title{
THE INFLUENCE OF THE LEADERSHIP AND CHARACTER OF A PASTOR ON THE SPIRITUAL GROWTH OF THE CONGREGATION AT THE GPdI ALFA OMEGA CHURCH.
}

\author{
Setya Hari Purnomo ${ }^{1)}$ Daniel Ari Wibowo ${ }^{2)}$ \\ 1) Evangelical Theological Seminary of Indonesia - Surabaya \\ E-mail:setyahari@sttii-suraaya.ac.id \\ 2) Evangelical Theological Seminary of Indonesia - Surabaya \\ E-mail:danielariwibowo@sttii-surabaya.ac.id
}

\begin{abstract}
Leadership is a task given by Jesus Christ to Christians through His Church. Leaders are needed by every human being to achieve happiness and prosperity in all fields. Thus the Church has an important role in improving leadership for the spiritual growth of God's congregation because through qualified leaders people can understand correctly how to actually follow God. With this quality leader, people can understand who and for what God created them. Seeing the existence of a congregation that always needs guidance in spiritual growth, and that requires someone who can accompany The congregation is a leader or shepherd who is often referred to as the Pastor of the congregation. And not many Christian ministers or often referred to as Congregational Pastors have these criteria. So that they cannot be an example in the lives of the people they lead. So there are criteria set out in the Bible to become a Christian leader with quality and character. A leader is someone who deserves to be a role model for others because the leader has good character and becomes a leader blessing for the church he leads.
\end{abstract}

Keywords: Leadership, Church, Congregation, Character, Pastors.

\section{INTRODUCTION}

A leader is "someone who has followers".[1] According to the Diktat Leadership, it is said: "a person who guides the activities of others but he himself is also actively working to realize those activities or someone who has the ability to direct others to achieve a goal he has achieved".[2] From the above understanding, a leader must be able to lead others and must be an example for the people he leads.
Vice versa, ideally someone who sets a good example should be appointed as a leader, of course, has a good character. However, there are many things that make this idealism unable to be realized and also expressed in everyday life. Because his character is not a blessing, instead becomes a stumbling block for others. Before going any further, it is necessary to look at the main meaning of leadership. "Leadership is the process 
of influencing or setting an example by the leader to his followers in an effort to achieve certain goals.

The natural way of learning leadership is "doing it at work" with practices such as the roasting of a skilled artist, craftsman, or practitioner. In this connection, the expert is expected as part of his role in providing teaching or instruction.[3] If you pay attention to the quote above, it will be very clear the correlation between leadership and character. It is said that a leader "does" in work with the aim of giving instructions to those who led.

This means that you need to be an example first to be a leader, let alone a shepherd. Because everything that is done and said is always highlighted by every congregation that will be pastored. Before deciding to actively participate in church stewardship or ecclesiastical management, an activist should be aware that there is a Christian word behind social stewardship and management which generally applies in the secular world. Christian stewardship and ecclesiastical management are complete devotion to God through service to others, so that there is a uniqueness in these two activities that are different from the standard stewardship and management in general.
Confidence, ability, and skill aren't an unconquered team. Five, Teamwork (Cooperation). The strength of a group is not me but we, is not mine but ours, because teamwork is a catalyst that yields excellence from shared strengths. Six, Family (Family). A happy life and good leadership start from a harmonious family.

Seven, Faith (Faith). Without faith, no one pleases God. Take the first step in faith. You don't have to see the whole staircase, just take the first step. Eight, challenge (Face the Challenge). Challenges make you discover things about your self that you never really knew. Nine, Solution. With a guiding light, all obstacles can be overcome. Ten, Balance (Able to $\mathrm{Be}$ Balanced). Balance is the key to life. Eleven, Love .

Love does not consist in gazing at each other, but in looking outward together in the same direction. Twelve, Discipleship. Without discipleship, no one can be a true Christin leader. Of the twelve criteria that have been written, there must be a leader so that he can bring others to be better led, but that is sometimes difficult to be fulfilled by every activist or church servant who is involved in the ministry every day. 


\section{RESEARCH METHOD}

Survey research method with a quantitative approach (Quantitative Research) is a research method selected in this study to answer the research questions.[4] The purpose of quantitative methods is not only to explain a problem but to produce generalizations. Generalization is a statement of truth that occurs in reality about a problem that is expected to applyin a population.

This statement is expressed in numerical form. Therefore, quantitative research methods use quantitative mathematical calculation techniques, so that they can produce a conclusion that applies in general a parameter. The author uses quantitative research because this method is suitable for the scientific work being carried out in this research.

\section{RESULTS AND DISCUSSION}

\section{Understanding of Leadership}

The author seeks to explain the definition of leadership. Leadership has been a topic of great interest to historians and philosophers since time immemorial. Since then experts have offered 350 definitions of leadership. One expert concluded that "Leadership is one of the easiest phenomena to observe but one of the most difficult to understand." Defining leadership is a complex and difficult problem because the nature of leadership itself is very complex. A lot of people talk about leadership issues, but often the essence is not clear and the influence and consequences of his leadership are not visible. Leadership is like the head with the body, where when the head hurts, the rest of the body hurts too.

Because in the hands of a leader, many decisions are very important and will determine the condition of the church, and spiritual growth will also have an impact on the number of people in the church. However, the development Science today has brought a lot of progress so that the understanding of leadership becomes more systematic and objective.is a mutually influencing relationship between leaders and followers (subordinates) who want real change that reflects shared goals.

Leadership involves influencing relationships deep, that happens among people who want change significant and the changes reflect the goals shared by leaders and followers (subordinates). Influence, in this case, means the relationship between the leader and his followers is not something passive, but a reciprocal and non-coercive relationship. Therefore Leadership itself is a process of mutual influence. Leader affects their subordinates and vice versa.

The people involved in the relationship want a change so that the leader 
is expected to be able to create significant changes in the organization. Furthermore, the change is not something the leader wants, but rather the goals (purposes) that are desired and shared. The goal is something that is desired, expected, which must be achieved in the future so that this goal becomes the main motivation for the vision and mission of the organization. Leaders influence followers to achieve change in the form of desired results together.

According to Robert W. Terry, leadership is the process of directing and influencing activities related to the tasks of group members. From this definition, it can be described as follows: First, in leadership, there must be other figures involved (as subordinates or followers). Second, there is a distribution of power that unequal in the group, namely between the leader and the led. And Third, in leadership, there must be someone who acts as a leader and can influence the group to carry out their duties so that the goals can be achieved. [5] According to Vance Packed, leadership is a way of getting other people to do what you think needs to be done. [6]

On the other hand, Kenneth O. Gangel said, "Leadership is a certain action which, at a certain time, will succeed in changing the behavior of the group towards mutually acceptable goals."[7] The leadership process also involves desire and intention, active involvement between leader and follower to achieve shared goals. Thus, both leaders and followers take personal responsibility for achieving the common goal. There are almost as many different concepts or definitions of leadership as there are people who have attempted to define it. However, there are many similarities between these definitions which allow for a rough classification scheme.

One, Leadership is the focus of group processes. Leadership is the superiority of a person or individuals in a group, in control of social phenomena. Leaders are always at the core of tendencies and On the other hand, all social movements when examined carefully will consist of various tendencies that have this core. The leader is the central figure who unites the group. The leader cannot be separated from the group, will but may be viewed as a position with high potential in the field.

Leadership is a function of the needs that arise in certain situations and consists of the relationship between the individual and the group.

Two, Leadership as a personality and its consequences. Leadership equals the power of personality. Leadership is a combination of various traits that allow individuals to influence others to do certain tasks. Leadership can be viewed as the 
formation and a state of behavior pattern that can put others under its influence. Three, Leadership is the art of influencing others. Leadership is the ability to handle others to get maximum results with as little friction as possible and great cooperation. Leadership is a creative and purposeful spirit/moral force. Leadership is an ability that give the impression of the leader's desire, so that it can lead to obedience, respect, loyalty, and cooperation.

Leadership is the art of influencing others to do what is expected of others to do. Leadership is the improvement, maintenance, and direction of moral unity to achieve the ultimate goal. Four, Leadership is the use of influence. A leader can be thought of as an individual who exerts a positive influence through his actions on others. Leadership is an interpersonal influence, which is practiced in a situation and directed through the communication process to achieve goals. Five, Leadership as action or behavior. Leadership can be defined as the behavior of an individual who says activities in groups.

Six, Leadership as a form of persuasion. Leadership is the management of people through persuasion and interpretation rather than through direct coercion. Leadership has the ability to influence people and generate a sense of security through an emotional approach through authoritarian use. Leadership is the art of relationship with others, is the art of influencing people through persuasion with concrete examples.

Seven, Leadership as a power relationship. Leadership is a type of power relationship characterized by the perception of group members about the rights of group members to determine behavior patterns that are following group activities. Leadership is a form of relationship between humans/individuals that requires conformity with the actions of each individual. Eight, Leadership as a means to achieve goals. Leaders are individuals who have programs, plans and together with group members move to achieve goals in a definite way. Leadership is the process of creating situations so that group members, including the leader, can achieve common goals with maximum results in a short time. Nine, Leadership as a result of the interaction. Leadership is not a cause or controller, but rather a result of group action.

Ten, Leadership as role differentiation. Leadership is a role in a relationship scheme and is determined by mutual expectations between the leader and other members. Eleven, Leadership as the initiation of the structure. Leadership is initiating and maintaining a structure of expectations and interactions. 
Leadership can mean many things. Leadership is not a particular title, title, or style. Those things are just decorations or accessories in leadership.

In an organizational environment, leadership occurs through two forms, namely formal leadership and formal leadership informal leadership. Formal leadership occurs when in the organizational environment, the position of formal authority in the organization is filled by people who are appointed or selected through a selection process.

Whereas Informal leadership occurs, where the position of the leader in an organization is filled with people who appear and influence others because of special skills or various sources that they have been considered capable of solving problems organizational problems and meet the needs of members of the organization who concerned.[8]

According to Syaharudin in the Indonesian dictionary, the word leadership comes from the world leader, which means a person who leads and gives instructions/guidelines. While leadership is a matter of leading and how to lead.[9]

Various studies on leadership have given birth to various approaches in leadership studies. Panji Anoraga wrote in his book entitled Psychology of Leadership, that there is an approach to measuring the value of a person's leadership, which is grouped into three parts, namely: First, the approach to the character. From the trait approach, a leader can be seen as a combination of traits (traits) that are very visible from a person leader so as to make this leader reach the level of leadership.[10]

The second, the behavioral approach. In this behavioral approach can be identified behaviors (behaviors), each person associated with effective leadership. The behavior of a leader will affect the continuity of his leadership, both in the period he is living or in the future, even for the next leadership. And the third, situational approach. This approach states that the situation and conditions of leadership determine the effectiveness of the leadership. Appreciation from people around him, especially employees, can be a support for his leadership.[11]

In general, leadership is a process of someone who is able and can lead, where a leader must also have the ability to influence others and direct the behavior of others, to achieve mutually agreed goals.[12]

\section{Understanding of Character}

If seen literally the word "character" is closely related to human personality. According to the Big Indonesian Dictionary, character means "psychological, moral or character traits that 
distinguish a person from others". other." This means that human characters are not the same as each other, so the character is a way of behaving and behaving that characterizes each individual to live and work together, both within the family, community, nation, and state.

Character is a reaction that arises or is born from emotions, such as angry, indifference, straightforward in speaking, arrogance, and so on. As J. John wrote in his book entitled 26 Keys Of Happiness, he said that character shows the nature of responsibility, honesty, courage, and caring, which we all know. have.

Character is the sum of all the internal qualities we possess. Characters are easier to save than repair. Character is important because it controls our lives and the way we act in various situations.[13] So, the character reflects the whole life of a person. If someone has a good and strong character, he will be judged well by others, especially in his attitude to interact as a social being.

The meaning of character in Latin means "tools for marking to"engrave." which means that character is "the process of sculpting the soul, marking oneself or carving oneself in such a way, so that it is unique, interesting and different. Character comes from Greek, which means to mark and focus on how to apply the value of goodness in the form of action or behavior.
So that people who are dishonest, cruel, greedy, and behave badly can be said that the person has bad character.

Conversely, people who behave in accordance with moral rules are called noble characters. Noble character means that the person has knowledge of his potential, which is characterized by values such as reflective, confident, rational, logical, critical, analytical, creative and innovative, independent, healthy living, responsible, love of science, patient, careful, and so on.

\section{Hypothesis Testing One. The Effect of Pastoral Leadership}

The first hypothesis is the influence of the Pastor's leadership on the spiritual growth of the congregation at GPdI "Alfa Omega" Based on the results of descriptive statistical tests on the variable of the influence of the Pastor's leadership (X1), the intervals were found according to the following table:

\begin{tabular}{|c|c|c|c|c|}
\hline & & & Statistic & $\begin{array}{l}\text { Std. } \\
\text { Error }\end{array}$ \\
\hline$Y$ & $\begin{array}{c}\text { Me } \\
95 \% \\
\text { Confidence } \\
\text { Interval for } \\
\text { Mean } \\
5 \% \text { Trimm }\end{array}$ & $\begin{array}{l}\text { Lower } \\
\text { Bound } \\
\text { Upper } \\
\text { Bound } \\
\text { Mean }\end{array}$ & $\begin{array}{l}34,40 \\
33,48 \\
35,32 \\
34,43\end{array}$ & ,459 \\
\hline
\end{tabular}




\begin{tabular}{|c|c|c|} 
Median & 34,00 & \\
Variance & 10,531 & \\
Std. Deviation & 3,245 & \\
Minimum & 28 & \\
Maximum & 40 & \\
Range & 12 & \\
Interquartile Range & 5 & \\
Skewness &, 099 &, 337 \\
Kurtosis &,- 742 &, 662 \\
\hline
\end{tabular}

Test Hypothesis two: Effects of the Shepherd's Character

The second hypothesis is the influence of the pastor's character on the spiritual growth of the congregation at GPdI "Alfa Omega". Based on the results of descriptive statistical tests on the variable influence of Shepherd's character (X2), the intervals were found according to the following table:

\begin{tabular}{|cc|c|c|}
\hline \multicolumn{4}{|c|}{ Descriptives } \\
& & Statistic & $\begin{array}{c}\text { Std. } \\
\text { Error }\end{array}$ \\
\hline \multicolumn{2}{|c|}{ Mean } & 34,40 &, 459 \\
95\% & Lower & 33,48 & \\
Confidence $\quad$ Bound & & \\
Interval for & Upper & 35,32 & \\
Mean & Bound & & \\
5\% Trimmed Mean & 34,43 & \\
Median & 34,00 & \\
Variance & 10,531 & \\
Std. Deviation & 3,245 &
\end{tabular}

\begin{tabular}{|c|c|c|} 
Minimum & 28 & \\
Maximum & 40 & \\
Range & 12 & \\
Interquartile Range & 5 & \\
Skewness &, 099 &, 337 \\
Kurtosis &,- 742 &, 662 \\
\hline
\end{tabular}

\section{Test Hypothesis Three: Congregational}

\section{Spiritual Growth}

The third hypothesis is the spiritual growth of the congregation at GPdI Alfa Omega. Based on the results of descriptive statistical tests on Variable spiritual growth of the congregation in GPdI "Alfa Omega" (Y) found the interval according to the following table:

Descriptives

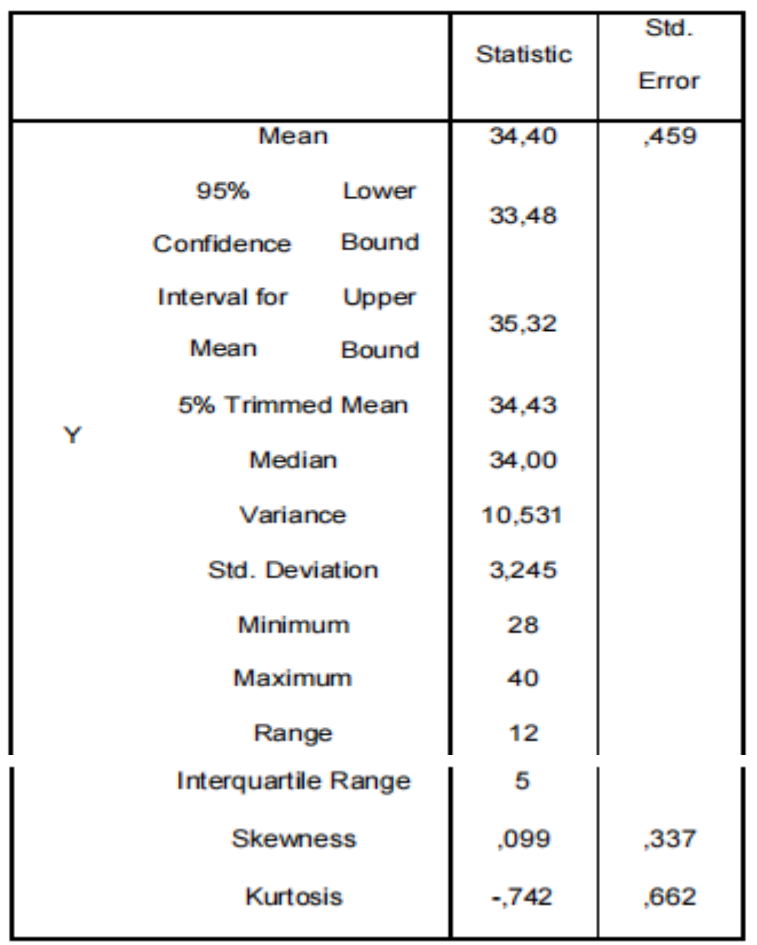


From the results of the simple regression statistical test between the influence variables The leadership and character of the Pastor (X) on the spiritual growth of the congregation at the GPdI "Alfa Omega" Ketintang Baru, Surabaya (Y) obtained results such as the table below:

\section{Simple Correlation Calculation Results} between $\mathrm{X}$ and $\mathrm{Y}$

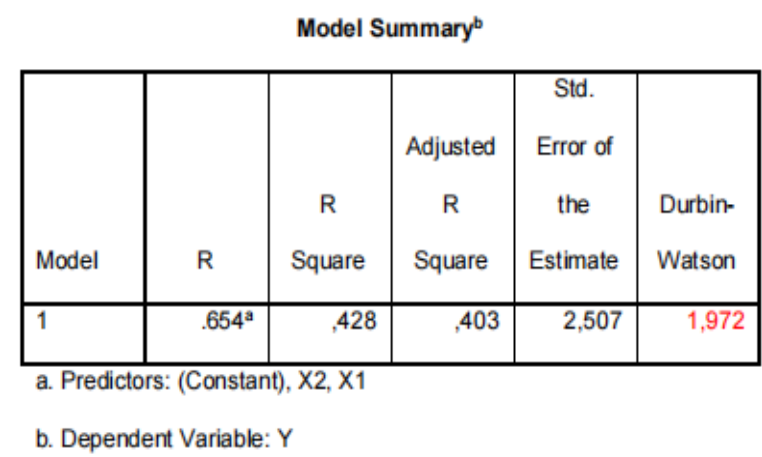

Based on the table above, the ryx value was found, which was 0.654 and was positive. Which means, the magnitude of the relationship between the influence of leadership and the character of the Pastor on congregational growth is 0.654. Based on the guidelines for providing interpretation of the correlation coefficient are as follows:

$0.00-0.199=$ very low

$0.20-0.399=$ low

$0.40-0.599=$ moderate

0.60-0.799 = height

$0.80-0.1000=$ very high

So the relationship between the variables $\mathrm{X}$ and $\mathrm{Y}$ is included in the category of high relationship. The direction of the relationship between the two is positive, which shows that the better the leadership and character of the Pastor, the better the spiritual growth of the congregation at GPdI "Alfa Omega" Ketintang Baru, Surabaya. Thus otherwise. The results of the analysis also obtained the value of ryx 2 (coefficient of determination) of 0.428 or $42.8 \%$. while the remaining $57.2 \%$ is explained by other reasons outside the research model.

The regression significance test between $\mathrm{X}$ against $\mathrm{Y}$ is described in the table below:

\section{Regression Significance Test between $X$ against $\mathbf{Y}$}

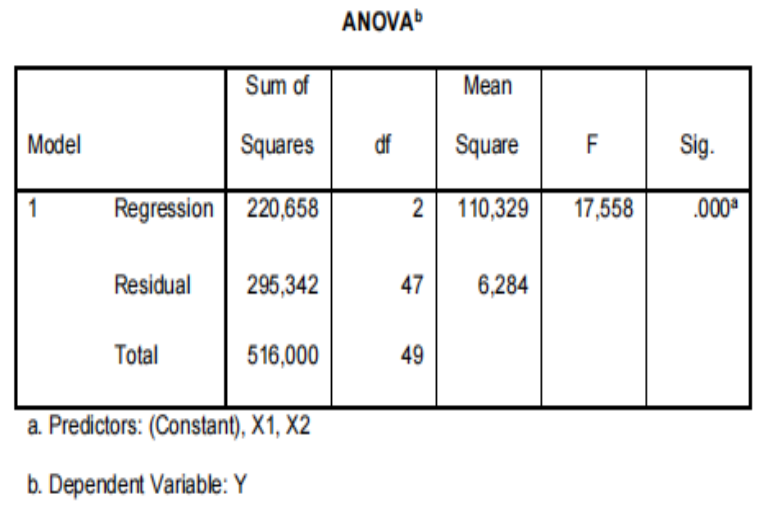

Based on the table above, the F of 17.558 with a value of $=0.005$ turned out to be significant at $<0.05$. It was concluded that the relationship between leadership and the character of the pastor on the spiritual growth of the congregation was at $<0.05$. 
Simple correlation significance test between $\mathrm{X}$ and $\mathrm{Y}$

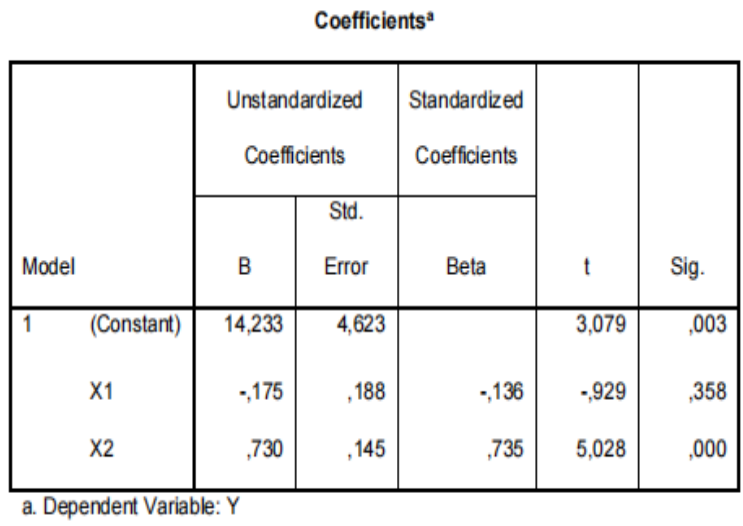

When viewed from the population, the value of $\mathrm{t}$ is 3.079 and it is significant at < 0.05. It means that the variables of leadership and the character of the pastor have a significant effect on the variable of spiritual growth congregation.

After doing the research, we can see that the congregation feels that the character of the Pastor is more influential on the spiritual growth of the congregation than his leadership. But it is undeniable, if these two things can be fulfilled, with good character and leadership, it can bring the spiritual growth of the congregation to a good direction as well.

\section{CONCLUSION}

At present, leadership in a church has a significant impact on all activities in the church. Unity or not uniting and growing or not a local church, especially in terms of the spiritual growth of the congregation, is determined by leadership and character.

Pastor of the congregation who plays a role in it. As described and explained by the author in chapter two As a theoretical study, it can be concluded that: One, in the leadership of the Pastor, a Pastor should be able to keep his words well and be able to manifest them in his actions in everyday life, both in behavior, love, loyalty and also in his chastity.

Thus, the spiritual growth of the congregation will become better and the congregation will live more fearing the Lord. Two, in the character of the Pastor, he should always be a good servant, have the fighting power and hope in the Lord Jesus, maintain steadfastness in teaching and have the dedication to God's Word, and have responsibility for his calling.

Thus, the spiritual growth of the congregation will be better. And based on the formulation of the problem in the introduction which has been partially answered on the theoretical basis, also based on the research process and research results, as well as the overall discussion which has been described in great detail from the first chapter to the fourth chapter, the author makes a decision or conclusion as a closing. Some of these conclusions are as follows:

First, the congregation's response to the 
influence of the Pastor's leadership which has a positive and positive influence on the congregation at the GPdI "Alfa Omega" Ketintang Baru, Surabaya, can be said to be overall good.

Second, respondents' responses to the character of the Pastor in general overall are good. Third, the understanding of the congregation based on their response to the spiritual growth of the congregation as a whole can be said to be good. This is the agreement of the respondent or the congregation on the material presented during the research process that has good and very good scores or agrees and strongly agrees. In other words, the author concludes that "The Influence of Leadership and Character of the Pastor on the Spiritual Growth of the Congregation at GPdI "Alfa Omega" Ketintang Baru, Surabaya is very important. Useful and is a scientific work that can be tested or can be justified.

\section{REFERENCES}

[1]. Pius Adi Atmadja, Diktat Lectures: Church Service Management, Sem. VII,2009,1.

[2]. I Nyoman Sudiarsa, Diktat Kuliah: Kepemimpinan, Sem. VII,2009,2.

[3]. John Adair, Cara Menumbuhkan Pemimpin (Jakarta: Gramedia Pustaka Utama,2000).

[4]. https://ejournal.upi.edu/, Pengaruh
Media Pembelajaran Terhadap Mutu Pembelajaran Pada Sekolah Dasar Terakreditasi A. DOI: 10.17509/mimbarsd.v3i2.4259.

[5]. Robert W. Terry, Authentic Leadership (Jakarta: Interaksara, 2002), 28.

[6]. Quoted in Leaders on Leadership (Ventura: Regal, 1997), 21.

[7]. Fostering Christian Education Leaders (Malang: Gandum Mas, 2001), 14.

[8]. Wahjosumidjo, Principal Leadership, Theoretical Review and Its Problems, (Jakarta: RajaGrafindo Persada, 2005), 84.

[9]. Big Indonesian Dictionary (Jakarta: Balai Pustaka, 2008)

[10]. Pandji Anoraga, Psychology of Leadership (Jakarta: Rineka Cipta, 2010). $15-16$.

[11]. Pandji Anoraga, Psychology of Leadership (Jakarta: Rineka Cipta, 2010). 16

[12]. Jerald Greenbreg, Robert A Baron, Behavior in Organizations (t.k.: t.p., 1997), 433.

[13]. J.John, 26 Keys Of Happiness (London: Hodder \& Stoughton Ltd, 2007), 43. 